\title{
XXIV. Experiments to ascertain whether there exists any affinity betwixt carbon and clay, lime and silex, separately or as compounds united with the oxide of iron forming iron ores and iron stones
}

\section{David Mushet Esq.}

To cite this article: David Mushet Esq. (1804) XXIV. Experiments to ascertain whether there exists any affinity betwixt carbon and clay, lime and silex, separately or as compounds united with the oxide of iron forming iron ores and iron stones, Philosophical Magazine Series 1, 19:74, 137-141, DOI: 10.1080/14786440408676539

To link to this article: http://dx.doi.org/10.1080/14786440408676539

$$
\text { 曲 Published online: } 18 \text { May } 2009 .
$$

Submit your article to this journal ए

\section{山ll Article views: 2}

Q View related articles ¿ 
sation taking place on the other side of the large piston which is open to the condenser; and that waste of steam which takes place in engines worked only by the expansive force of steam, from steam passing the piston, is prevented f for all steam that passes the piston in the smaller cylinder is received into the larger.

"In such an engine, where it may be more convenient for any particular purpose, the arrangement may be altered, and the top of the smaller made to conmunicate with the top of the larger, and the bottom of the smaller with the bottom of the larger cylinder; in which case the only difference will be, that when the piston in the smaller cylinder descends, that in the larger will ascend, and while the latter descends the former will ascend, which for some particular purposes may be more convenient than the ar rangement before described."

Mr. Woolf then proceeds to describe various other modifications of his invertion, and points out means for applying his improvements to the working of steam-engines already constructed and now in use, of which we shall give sóme account in our future numbers.

We cannot, bowever, conclude without observing that the benefits likely to result to the manufacturing interests of this country by Mr. Woolf's improvepnent of the steamengine, cannot possibly be calculated. On this we shall offer a few thoughts on some future opportunity.

XXIV. Experiments to ascertain whether there exists any Affinity betuixt Carlon and clay, Lime and Silex, separately or as Compounds united with the Oxide of Iron forming Iron Ores and Iron Stones. By David Mushet, Esq. of the Calder Iron-Works.

\section{[Continued from p. 4o.]}

$T_{\text {he following experiments were made with a view to }}$ unite carbon $x$ ith silex by fusion.

I. Some pieces of very transparent quartz were introduced alone in to a Sturbridge clay crucible, and exposed to a heat of $16:)^{\circ}$ of Wedgwood. When cold, and examined, I found the form and rumber of the crystals entire. The surfaces were slightly vitrified: the colour white pearly. The interior of each crystal was spongy, and adhesive to the tongue. 
II. Fifty grains of this roasted quartz were pulverized and mixed with 3 grains of lamp black. The colour of the mixture was blueish black. I exposed it in a Cornwall clay pot to $170^{\circ}$ of Wedgwood; but found the contents unfused, and still pulverulent. The mixture had become nearly of a black colour, but the fragments of silex remained unchanged.

III. Fifty grains of roasted quartz, mixed with half a grain of lamp black, were exposed in a similar manner as No. II. The result was the quartz in as pure and unfused a state as when introduced. The half grain of lamp black was nearly dissipated, and had communicated a shining lead colour to the interior of the crucible.

IV. A crystal of quartz possessing great depth of water was found 20 weigh $36 \frac{1}{2}$ grains. It was afterwards, for six hours, exposed in a bright red heat; when it was found to have lost nearly half a grain. The lustre and shape of the crystal remained unchanged.

$V$. The same crystal, after losing a small fragment, weighed $35 \frac{1}{2}$ grains. It was then exposed to $168^{-}$of Wedgwood. It was found shivered into a number of small pieces of a pearly white colour tinged with blue. A few fragments still possessed their original angle and transparency. The whole were carefully collected, and w eighed only a quarter of a grain less than when introduced. In this experiment a total change was effected upon the subject, but scarcely any less of weight could be reckoned.

VI. I took two crystals of quartz, weighing 42 grains, and introduced them into a Cornwall clay crucible filled with charcoal. The heat to which they were exposed was nearly $170^{\circ}$. When examined, the following was found to be the result. The crucible was found still nearly filled with charcoal. The two crystals, with the exception of one small fragment, remained entire, though fritiered a good deal. Excepting where the charcoal had entered the fissures, there was not the most distant appearance of contact, or any combination betwixt the sificeous matter of the quartz and it. The crystals had entirely lost their transparency, were posseszed of a whitish cnamclled surface, and seemed spongy in the centre. Their wcight was 41 grains; and if the small portion of carbonaceous matter be taken into the account, which had entered the fissures, not more than 3-4ths of a grain was lost, of weight, in the exposure. This experiment proves that the combination of carbon with the matter of silex and clay, which constitutes quartz, takes place at a higher temperature than $170^{\circ}$ of Wedgwood, and ren- 
ders it highly presumable that the affinity is not excited in any degree of heat short of fusion.

VII. 50 grains of roasted quartz, pulverized,

5 ditto pure lime.

These were exposed, in a Cornwall clay crucible, to $167^{\circ}$. The result of this was a semi-vitrified mass, granulated, pure in colour, and very hard. The angles cut glass with considerable facility.

VIII. 50 grains of roasted quartz,

jo ditto pure lime, were softened into a white mass of porcelain, possessing a slight tint of azure.

IX. 50 grains of roasted quartz,

15 ditto pure lime, were melted into a whitish mass covered with some very perfect glass. The fracture was dense throughout, though not homorgneous.

X. 50 grains of roasted quartz,

15 ditto pure lime,

1 ditto lamp black, formed a solid mass of glass of a lead-blue colour. The carbonaceous matter had disappeared.

XI. 50 grains of roasted quartz,

15 ditto pure lime,

2 ditto lamp black.

This mixture fused, and formed a very black glass considerably spongy. The charcoal had, as in former experiments, disappeared. In this experiment, the interior of the crucible of Cornwall clay had received the usual glaze observed in experiments where the quantity of carbon made use of approaches nearly to that which the mixture is capable of taking up.

XII. 50 grains of roasted quartz,

15. ditto pure lime,

3 ditto lamp black.

This mixture was fused into a honey-combed mass of darkcoloured glass possessed of neither beatity nor transparency. A portion of the lamp black remained in its original state, partly enveloped in the mass and partly upon the surface. It was found to amount to nearly half a grain. The quantity, therefore, taken up by the quartz in this experiment, supposing the pare lime remained neutral, is exactly equal to $1-20 \mathrm{th}$; and, by the combination of this proportion of carbon, the pure white porcelain, produced in Experiments VIII and IX, is changed into a honey-combed mass of black glass.

XIII. Fifty grains of pure silex were introduced into a Cornwall clay crucible, and exposed to a heat of $170^{\circ}$ of 


\section{On the Affinities of different Earths for Cartion.}

Wedgwood. I found the silex fused into a rich pearlish green glass containing an immense number of air-bubbles. A minute speck of colour was noticed in one part, which rescmbled coal. The experiment was therefore repeated a sacond and third time; and the fused silex obtained in a state of great purity as to colour, though still containing a number of minute cells.

$\mathrm{XIV}$. Fiffy grains of pure silex and a quartes of a grain of lamp black were mixed. The carbon gave a delicate shade of blue to the silex. The mixture was fused into a singular glass composed of concentric lamina or convexes of thin glass. The colour was indefinite and mixed, of a straw, watery, smoky linge, and much clouded. It was, however, very transparent, and so buoyant as to float in air.

$\mathrm{XV}$ : 50 grains of pure silex,

$\frac{1}{2}$ grain of Jamp black, were fused into a porous. glass possessing a watery transparcncy, but of a light lead-. blueish colour.

XVI. 50 grains of pure silex,

1 grain of lamp black, formed a glass considerably darker in print of colour than the former: the cells were much of the same size, but the thickness of the lamina much increased, and the transparency proportionally diminished. - In these three experiments the carbon had completely disappeared, nor had the interior. of any of the crucibies exhibited the usual style of glazing.

XVII. 50 grains of pure silex,

$$
2 \text { ditto lamp black. }
$$

These were intimately mixed together, and exposed to a similar heat with the former. The result was a jet black glass much honey-combed, and apparently approaching a state beyond simple vitrification. The whole carbon had disappeared, and the interior of the crucible remained unglazed.

XVIII. so grains of pure silex,

3 ditto lamp black, were fused into an irregular mass of a very dark colour possessing large honeycombab. The transparency of the glass no longer existed, but a.minute porosity admitted light with a singular effect. The carbon had disappeared, and the crucible had received a slight degree of colour from the carbon.

XIX. 50 grains of pure silex,

5 ditto lamp black.

This mixture assumed an earthy appearance of a very black colour, in a ferw places slining, but in general dull. The boney'combed appearance was less in this than in the for- 
mer, and the porosity so visible in the last was considerably diminished. A portion of the carbonaceous matter remained untaken up which weighed 3-4ths of a grain, so that in this experiment $4_{4}$ grains of carbon had disappeared, and united with the silex. This is equal to $8 \frac{1}{2}$ per cent., or $1-12$ th part the weight of the silex.

It will not therefore appear rash to conclude, from these experiments, that carbon in high temperatures unites with siliceous matter in the same manner as indicated by the ex periments with clay, and that its colour and appearance are totally changed by the union.

The conclusions to be drawn from these experiments, and facts in general, so far as they regard the manufacture of iron, will present themselves with more force of reasoning connected with the analysis of artificial and natural iron ores, containing solely or in excess a particular earth of the before-mentioned varieties.

The present may be concluded with one general remark, that the carbon does not appear to enter silicenus matter by cementation, as was evident in exposing the two siliceous crystals No. VI. In the experiments with clay, not only a mass of Cornwall clay was pervaded by the carbon, but many of the crucibles used in all these experiments were frequently penetrated a considerable portion of their thickness.

[?! o be continue 1.$]$

XXV. Dr. Thonnton's Second Letter to Mr. Arthur Aikin.

July 10, 1804 .

SIR, No. I, Hind-street, Manchester-square.

I was almost morally sure that you could never have allowed such gross ignorance and abuse to have passed in your Annual heview, had you "been aware of it," as have been exhibited in the "critique" on my work. Certainly you must have been plonet-struck, when you read, probably, for the first time, in the letter I had the honour to address you, that, in your review, it was asscrted that the satellite of Venus had not been mentioned in any work on astronomy, and that this before unheard of moon was of my invention; which seemed to afford your reviewer an opportunity of spewing out a torrent of personal abuse against me. Such conduct could not fail to astonish one, who was in the habit of esteeming you before as a scholar and a gentleman, a character adopted from your learned father; and which. I should 